\title{
FOREST MANAGEMENT AND WATER QUALITY IN LATVIA: IDENTIFYING CHALLENGES AND SEEKING SOLUTIONS
}

Zane KALVITE, Latvian State Forest Research Institute 'Silava', Address:111 Rigas str, Salaspils, LV-2169, Latvia; zane.kalvite@silava.lv (corresponding author)

Zane LIBIETE, Latvian State Forest Research Institute 'Silava', Address:111 Rigas str, Salaspils, LV-2169, Latvia; zane.libiete@silava.lv

Arta BARDULE, Latvian State Forest Research Institute 'Silava', Address: 111 Rigas str, Salaspils, LV-2169, Latvia; arta.bardule@ silava.lv

Rise in human population, industrialization, urbanization, intensified agriculture and forestry pose considerable risks to water supply and quality both on global and regional scale. While freshwater resources are abundant in Lat via, during recent years increas ed attention has been devoted to water quality in relation to anthropogenic impacts. Forest cover in Latvia equals $52 \%$ and forest management and forest infrastructure building and maintenance are among the activities that may, directly or indirectly, affect water quality in headwater catchments. Sedimentation, eutrophication and export of hazardous substances, especially mercury (Hg), are of highest concern.

To address these topics, several initiatives have started recently. In 2011, cooperation programme between Latvian State Forest Research Institute (LSFRI) "Silava" and JSC "Latvia's State Forests" was launched to evaluate the impact of forest management on the environment. This programme included research on the efficiency of water protection structures used at drainage system maintenance (sedimentation ponds, overland flow) and regeneration felling (bufferzones). In 2016, within the second stage of this cooperation programme, a study on the impact of forest management on water quality (forest road construction, drainage system maintenance, felling) was started on a catchment scale.

Since 2016 LSFRI Silava is partner in the Interreg Baltic Sea Region Programme project "Water management in Baltic forests". By focusing on drainage systems, riparian zones and beaver activity, this project aims at reducing nutrient and $\mathrm{Hg}$ export from forestry sites to streams and lakes. While this project mostly has a demonstration character, it will also offer novel results on $\mathrm{Hg}$ and methylmercury $(\mathrm{MeHg})$ concentrations in beaver ponds in all participating states.

This paper aims at summarizing most important challenges related to the impact of forest management on water quality and corresponding recent initiatives striving to offer solutions.

Keywords: forest infrastructure building, forest management, water protection measures, water quality

\section{INTRODUCTION}

Eutrophication is one of the main water quality problems in the Baltic Sea since around mid-1900s, when primary productivity from excessive inputs of nitrogen and phosphorus increased considerably (Bonsdorff et al., 1997; Larsson et al., 1985). Concentrations of nitrogen and phosphorus, the main triggers of eutrophication, have risen in many areas of the Baltic Sea Region due to increased nutrient leaching following industry development and more intense land management from the 1950s onwards (Gustafsson et al., 2012). Although, on an areal basis, agricultural and urban lands export more $\mathrm{N}$ and $\mathrm{P}$ than forests, forests cover almost half of the Baltic Sea catchment area and low areal export rates may be offset by a large area (Högbomand Futter, 2013). According to Latvian River Basin Management Plans (2015), anthropogenic input fromforests in Latvia constitutes to $9.1 \%$ in average of the total Ninput (that varies from $5.5 \%$ to $16.5 \%$ in different regional planning areas). Forestry effects on run-off water quantity and quality have been reported in many studies. There is evidence that forestry activities may cause deterioration of water quality (Åströmet al., 2001; Ormerod et al., 1993), alteration of hydrological regime (Moore and Wondzell, 2005) and temperature increase in waterbodies (Danehy et al., 2005). The efficiency of water protection methods and biological responses to forest drainage remain largely unexplored (Louhi et al., 2010).

Another type of contamination are heavy metals and other hazardous substances originating from wastewater treatment plants, waste deposits, household materials and chemicals, atmospheric deposition from emissions of factories and other sources. Numerous contaminants degrade slowly so their negative effects can increase as they acc umulate in the aquatic food web. The current level of contamination is elevated in all parts of the Baltic Sea, mostly polybrominated diphenyl ethers and $\mathrm{Hg}$ (Helcom, 2017). Concentrations of $\mathrm{Hg}$ in fish tissue higher than the WHO recommendations as well as the U.S. Environmental Protection Agency criteria ( 0.5 and $0.3 \mathrm{mg} \mathrm{Hg} \mathrm{kg}^{-1}$ tis sue, respectively) commonly occur in large parts of the

Copyright (C) 2017 The Authors. Published by Aleksandras Stulginskis University. This is an open-access article distributed under the terms of the Creative Commons Attribution License (CC-BY 4.0), which permits unrestricted use, distribution, and reproduction in any medium, provided the original author and source are credited. 
hemiboreal zone. The European Union threshold limit of $0.02 \mathrm{mg} \mathrm{Hg} \mathrm{kg}{ }^{-1}$ tis sue is exceeded in many water bodies in the Baltic Sea Region. $\mathrm{MeHg}$ is one of the most toxic forms of $\mathrm{Hg}$ and effectively bioaccumulates in the food web. Forestry activities affecting soil hydrology, temperature, and redox conditions can influence $\mathrm{Hg}$ methylation rates as well as the mobilization of $\mathrm{Hg}$ and $\mathrm{MeHg}$ from soils to soil, surface, and ground waters (Eklöf et al., 2018). Several existing studies have found that various forestry activities can increase total $\mathrm{Hg}$ and $\mathrm{MeHg}$ concentrations in streams (Eklöf et al., 2012; Eklöf et al., 2013; Eklöf et al., 2014; Eklöf et al., 2016; Eklöf et al., 2018; Kronberg et al., 2016; Porvari et al., 2003). Beaver sites can have either positive or negative influence on the environment. Positive contributions can be decreased runoff s peed, increase in water carrying capacity and increase in biodiversity. At the same time the presence of beaver species may cause considerable damage to agricultural and forest lands. Distribution of beaver dams not only impact water quality through flow of nutrients, but under certain circums tances it can also have effect on the leaching of hazardous substances such as methylmercury that can be highly toxic and bio-accumulative, so it can negatively impact different species and riparian forest ecosystems.

Water protection is one of the main environmental priorities in Latvian environmental protection policy. Moderate or poor waterbody ecological quality status, increased nutrient leaching from intensely managed agricultural lands, poor habitat quality for several species, including some protected species, insufficient visual and recreational quality of riparian zones and lack of knowledge on appropriate management measures supporting or increasing ecosystemservices and only very poor data on the efficiency of these measures are the main is sues related to water quality that have been identified in Latvia. The aim of this paper is to briefly present three recent studies dealing specifically with water quality and forest management interactions in Latvia.

\section{MATERIALS AND METHODS}

The study areas of sedimentation ponds are located in Northern Kurzeme, Central Kurzeme and Central Vidze me, beaver dam removal impact is investigated in Southern Vidzeme (experimental forests of Kalsnava Forest district) and road construction impact is investigated in Eastern Zemgale (model territory of Zalve Forest district).

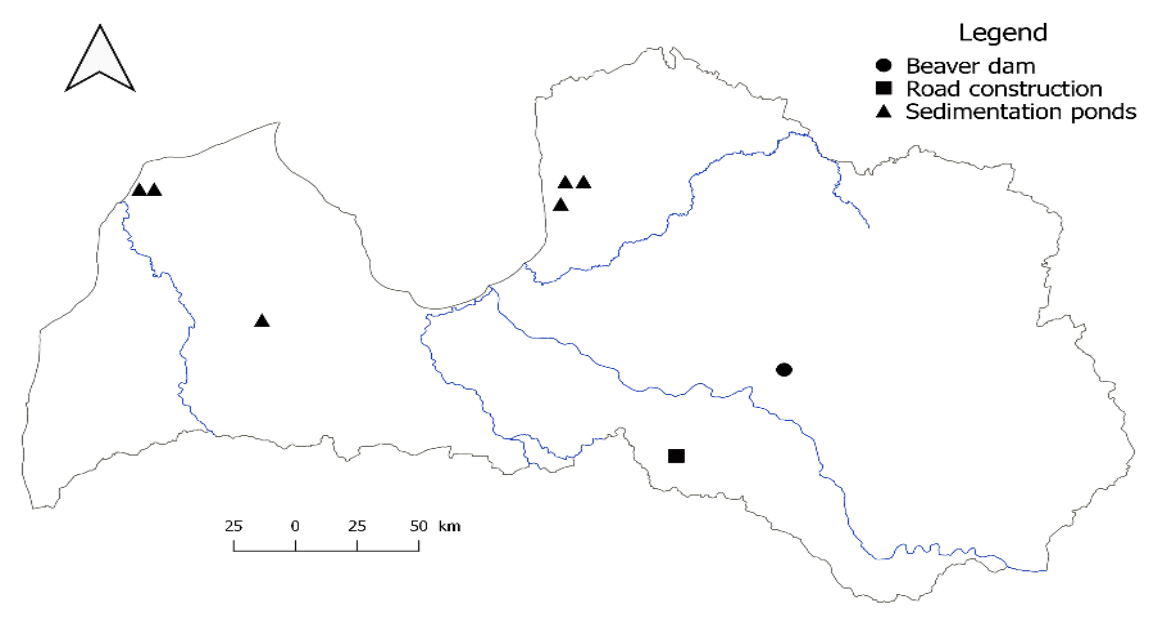

Figure 1. Location of research sites.

\section{Effectiveness of sedimentation ponds}

One of the most popular methods to reduce the potential negative impact of drainage system renovation is the establishment of sedimentation ponds before inflow of the main ditch in to the waterbody. The aim of the ponds is to slow down the water flow and to facilitate the sedimentation of particles. Establishment of sedimentation ponds is mandatory in the state forests if the length of drainage systemto be renovated exceeds $0.8 \mathrm{~km}$.

To test the efficiency of these structures, a pilot study in close cooperation with the JSC "Latvia's State Forests" was performed by LSFRI "Silava" from 2012 to 2014. Water quality parameters $\left(\mathrm{NO}_{3}-\mathrm{N}, \mathrm{NH}_{4}-\mathrm{N}, \mathrm{N}_{\text {tot., }}\right.$ PO $\mathrm{PO}_{4}-\mathrm{P}, \mathrm{K}, \mathrm{Ca}$, $\mathrm{Mg}$, TSS, DOC) were measured in samples taken in six drainage systems (BU1, BU2, ST1, ST2, VG, VA) in different parts of the country upstream and downstream of sedimentation pond s three years after the maintenance.

\section{The impact of road construction on water quality}

In 2016, monitoring of water quality parameters $\left(\mathrm{NO}_{3}-\mathrm{N}, \mathrm{NH}_{4}-\mathrm{N}, \mathrm{N}_{\text {tot }}, \mathrm{PO}_{4}-\mathrm{P}, \mathrm{K}, \mathrm{Ca}, \mathrm{Mg}\right.$, TSS, DOC) was started in a forested catchment (size - 2762 ha, $96 \%$ forest cover) in state forests where forest road reconstruction was planned in 2017. Samples were taken from the ditch at seven places where it crosses the road once a month. Information about exact location and timing of construction works was also available, therefore it was possible to determine the impacts more precisely. Currently data from 6 months' period before the reconstruction works started and 13 months after the start of works have been analysed.

\section{Beaver dam removal}

The effects of beaver dam removal on the general water chemistry, $\mathrm{Hg}$ and $\mathrm{MeHg}$ content in water, sediment and biota are investigated within the Interreg Baltic Sea Region Programme project "Water management in Baltic forests" (WAMBAF). Water samples were taken once a month from sampling points above the dam, in the beaver pond and below 
the dam. General water quality parameters $\left(\mathrm{NO}_{3}-\mathrm{N}, \mathrm{NH}_{4}-\mathrm{N}, \mathrm{N}_{\text {tot. }}, \mathrm{PO}_{4}-\mathrm{P}, \mathrm{K}, \mathrm{Ca}, \mathrm{Mg}, \mathrm{P}_{\text {tot. }}\right.$, TSS, DOC) were measured in samples at Forest Environment laboratory of LSFRI Silava, while $\mathrm{Hg}$ content was determined at Latvian Institute of Aquatic Ecology and MeHg content - at IVL, Sweden. At the same time general water quality was monitored also in a natural beaver site in protected area in close proximity to the study site.

\section{RESULTS}

\section{Effectiveness of sedimentation ponds}

The results of the study showed that sediment ponds used in the current practice are only partially effective. Total suspended solids concentration downstream of the sedimentation pond was even higher than before the pond during the drainage system renovation year (2012) and the following year. In 2014 concentration of total suspended solids was significantly lower downstream of the pond compared to upstreamreadings in most study sites. In the period of observations, decreasing trend of total suspended solids concentration was observed. Trends in changes of nitrogen compound concentrations were similar - after the year of drainage system renovation concentrations decreased in most study sites, although statistically significant differences were not detected. Decrease of phosphate concentrations was not detected downstreamof the sedimentation ponds, but concentrations in all sampling points decreas ed over time (Figure 2).

Generally, there was an indication of partially positive effect on the retention of suspended solids, but nutrients generally were not retained. The efficiency of sedimentation ponds also varied among the sites. As the most important factor to decrease the export of suspended particles and nutrients is the reduction of water flow velocity, it was recommended to combine sedimentation ponds with other measures that might be effective in this regard, e.g., sedimentation pits, uncleaned sections of the ditch. It was also recommended to establish larger sedimentation ponds, if possible, combining them with reservoirs for fire-fighting needs, basins for forest animals, etc. If possible, sedimentation ponds should be established one year before drainage sys temrenovation, so that the sides of the pond could stabilize, and the risk of erosion would be reduced.

\section{TSS}

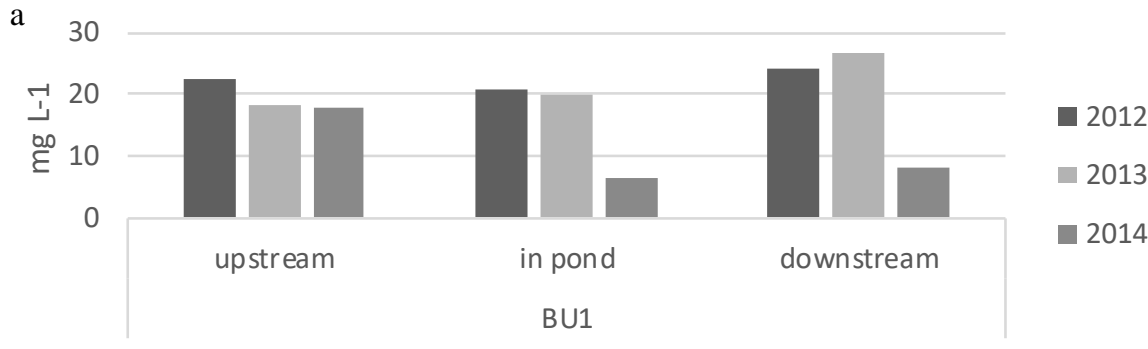

b N-NO3-

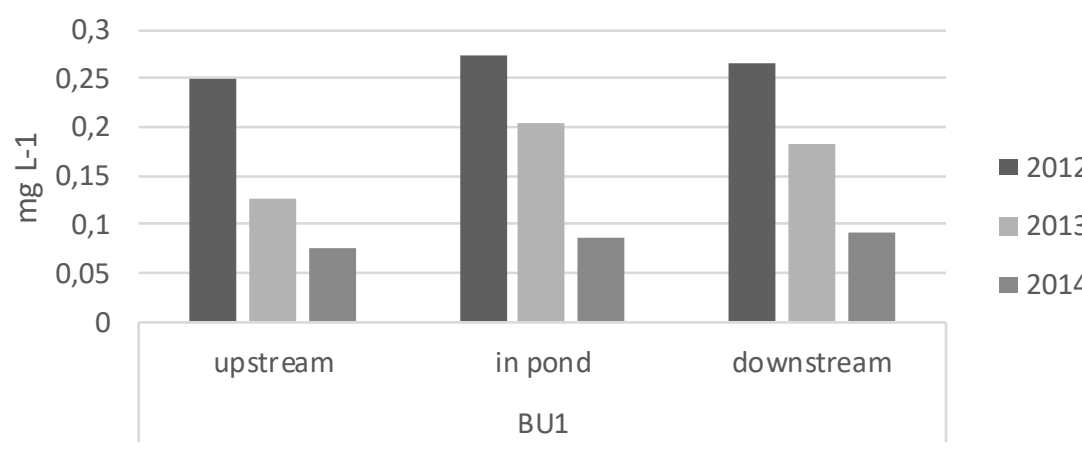

c P-PO43-

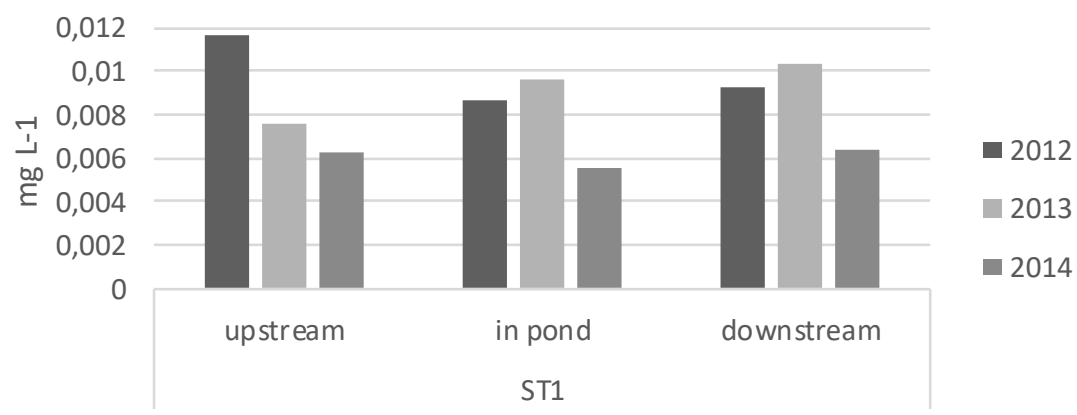

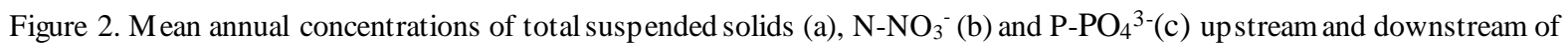
sedimentation ponds and in sedimentation ponds at different study sites. 


\section{The impact of road construction on water quality}

Sampling points (P2; P3; P4; P6) were located in places where forest roads cross ditches renovated in 2015. Reconstruction of the roads was carried out from September 2016 to August 2017. Generally, concentrations of total suspended solids were not significantly higher during and after the road construction works, except at the sampling point P6. Mean annual concentrations of totalN tended to increase in 2017, when compared to 2016 (Figure 3). However, when information on exact timing of works carried out in close proximity of the sampling points was analysed, no evident and significant influence on water quality indicators (dissolved oxygen content, turbidity, concentration of suspended particles, etc.) was detected. Forest management activities are still ongoing in the model area (felling in 2017/2018), water sampling is being continued and results of this research programme will be used to aid planning and decision making in the state forests of Latvia.

a Ntot.

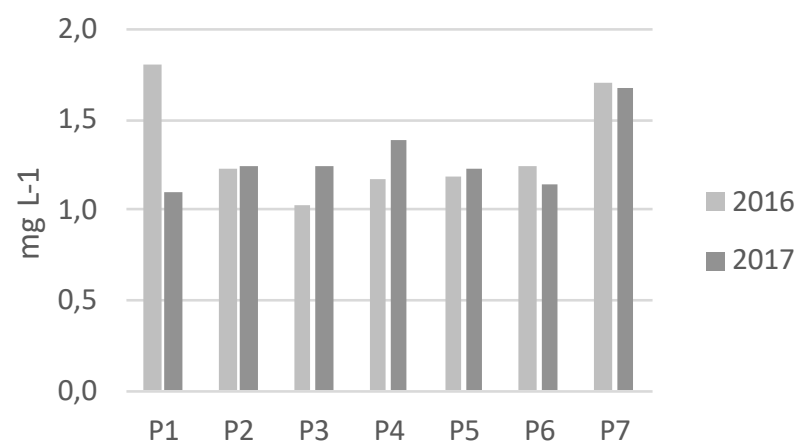

b

\section{TSS}

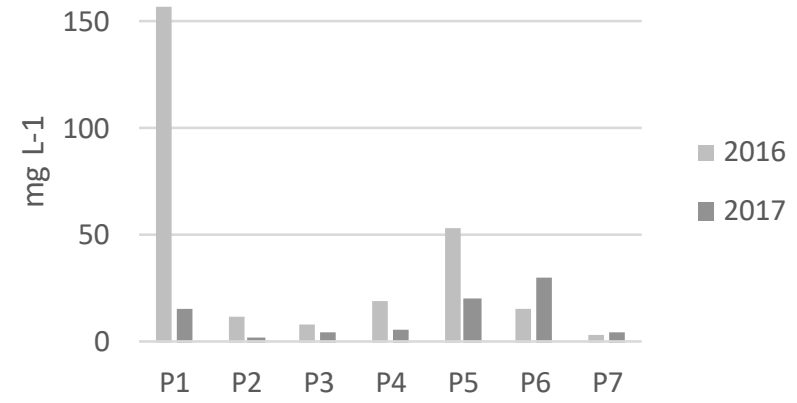

Figure 3. Mean annual total N (a) and total suspended solids (b) concentrations at the study sites.

\section{Beaver dam removal}

Generally, total nitrogen, total phosphorus and DOC concentrations in water demonstrated increasing trend after the beaver dam removal (Figure 4). Concentrations below the dam were slightly higher than those above, both before and after the dam removal. The lowest concentrations of nitrogen, phosphorus and DOC were detected in a natural beaver site in protected area. Correlations between the beaver management and changes in water quality, including interactions between different water quality parameters, e.g., DOC and $\mathrm{Hg}$, need to be further investigated to provide solid basis for decision making support systemfor the landowners. Based on economic and ecological evidence, such a syst emshould advise, whether the beaver dam should be removed or retained.

\section{CONCLUSIONS}

The efficiency of regular sedimentation ponds used in the state forests was higher in reducing the concentration of suspended particles but no significant effect on $\mathrm{N}$ and $\mathrm{P}$ was observed. Landscape characteristics, soil and forest types have to be carefully considered when planning drainage systemmaintenance, and implementation of additional measures may be required to reduce water flow velocity.

No direct and significant impact on water quality indicators after forest road construction was detected, research programme will be continued to investigate long-term effects.

$\mathrm{N}, \mathrm{P}$ and DOC concentrations in the water of beaver-impacted drainage systems are higher than those at natural beaver site. Dam removal increases the element concentrations in runoff. Following studies should focus on beaver activities in forest drainage systems and mercury methylation processes in beaver ponds should be further investigated. 
a

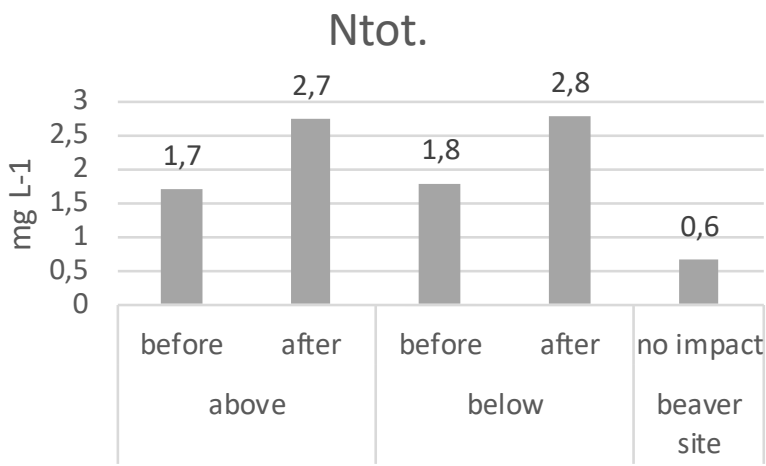

$\mathrm{b}$

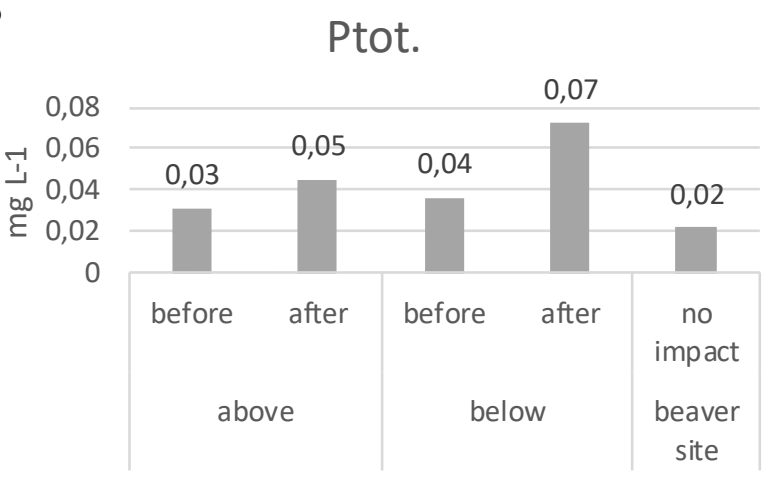

$\mathrm{C}$
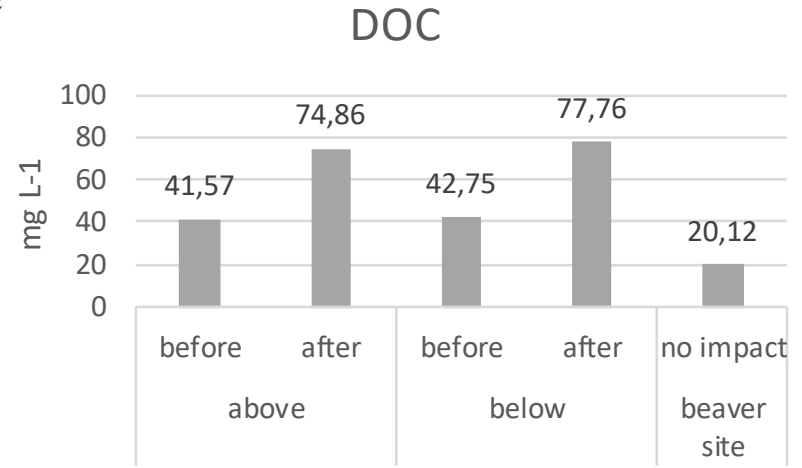

Figure 4. Mean total N (a), total P (b) and dissolved organic carbon (c) concentrations at the study sites.

\section{ACKNOWLEDGEMENTS}

In this publication data and information about the research programme "The impact of forest management on ecosystem services provided by forests and related ecosystems", implemented by LSFRI "Silava" with financial and technical support from JSC "Latvia's State Forests" and Interreg Baltic Sea Region Programme Project "Water management in Baltic forests" are used.

\section{REFERENCES}

1. Åström, M., Aaltonen, E., Koivusaari, J. 2001. Effect of ditching operations on stream-water chemistry in a boreal forested catchment. Science of the Total Environment, Vol. 279, pp. 117-129. https://doi.org/10.1016/S0048-9697(01)00757-4

2. Bonsdorff, E, Blomqvist, E.M., Mattila, J., Norkko, A. 1997. Long-term changes and coastal eutrophication. Examples from the Aland Islands and the Archipelago Sea, northern Baltic Sea. Oceanologica Acta, Vol. 20, pp. 319-329.

3. Danehy, R.J., Colson, C.G., Parrett, K.B., Duke, S.D. 2005. Patterns and sources of thermal heterogeneity in small mountain streams within forested setting. Forest Ecology and Management, Vol. 208, pp. $287-302$. https://doi.org/10.1016/j.foreco.2004.12.006

4. Eklöf, K., Bishop, K., Bertilsson, S., Björn, E., Buck, M., Skyllberg, U., Osman, O.A., Kronberg, R.M., Bravo, A.G. 2018. Formation of mercury methylation hotspots as a consequence of forestry operations. Science of the Total Environment, Vol. 613614, pp. 1069-1078. https://doi.org/10.1016/i.scitotenv.2017.09.151

5. Eklöf, K., Kraus, A., Weyhenmeyer, G.A., Meili, M., Bishop, K. 2012. Forestry influence by stump harvest and site preparation on methylmercury, total mercury and other stream water chemistry parameters across a boreal landscape. Ecosystems, Vol. 15, pp. 1308-1320. https://doi.org/10.1007/s10021-012-9586-3

6. Eklöf, K., Lidskog, R., Bishop, K. 2016. Managing Swedish forestry's impact on mercury in fish: defining the impact and mitigation measures. Ambio, Vol. 45, pp. 163-174. https://doi.org/10.1007/s13280-015-0752-7

7. Eklöf, K., M eili, M., Åkerblom, S., von Brömssen, C., Bishop, K. 2013. Impact of stump harvest on run-off concentrations of total mercury and methylmercury. Forest Ecology and Management, Vol. 290, pp. 83-94. https://doi.org/10.1016/j.foreco.2012.05.039 
8. Eklöf, K., Schelker, J., Sørensen, R., Meili, M., Laudon, H., von Brömssen, C., Bishop, K. 2014. Impact of forestry on total and methyl-mercury in surface waters: distinguishing effects of logging and site preparation. Environmental Science and Technology, Vol. 48, pp. 4690-4698. https://doi.org/10.1021/es404879p

9. Gustafsson, B.G., Schenk, F., Blenckner, T., Eilola, K., Meier, H.E.M., Müller-Karulis, B., Neumann, T., Ruoho-Airola, T., Savchuk, O.P., Zorita, E. 2012. Reconstructing the Development of Baltic Sea Eutrophication 1850-2006. Ambio, Vol. 41, pp. 534-548. https://doi.org/10.1021/es404879p

10. Helcom. 2017. Hazardous substances. Available at http://stateofthebalticsea.helcom.fi/pressures-and-their-status/hazardoussubstances/ (Accessed on 01/11/2017)

11. Högbom, L., Futter, M. 2013. Quantifying N, P and C losses to waters from Fennoscandic /Baltic forests and the effect of various forestry operations. Available at http://nordicforestresearch.org/wp-content/uploads/2017/09/SNS-110 Policy-Brief.pdf (Accessed on 13/11/2017)

12. Kronberg, R.M., Drott, A., Jiskra, M., Wiederhold, J.G., Björn, E., Skyllberg, U. 2016. Forest harvest contribution to Boreal freshwater methylmercury load. Global Biogeochemical Cycles, Vol. 30, pp. 825-843. https://doi.org/10.1002/2015GB005316

13. Larsson, U., Elmgren, R., Wulff, F. 1985. Eutrophication and the Baltic Sea - causes and consequences. Ambio, Vol. 14, pp.9-14.

14. Louhi, P., Mäki-Petäys, A., Erkinaro, J., Paasivaara, A., Muotka, T. 2010. Impacts of forest drainage improvement on stream biota: A multisite BACI-experiment. Forest Ecology and Management 260, pp. 1315-1323. https://doi.org/10.1016/j.foreco.2010.07.024

15. Moore, R.D., Wondzell, S.M. 2005. Physical hydrology and the effects of forest harvesting in the Pacific northwest: a review. Journal of the American Water Resources Association 41, pp. 763-784. https://doi.org/10.1111/j.1752-1688.2005.tb04463.X

16. Ormerod, S.J., Rundle, S.D., Lloyd, E.C., Douglas, A.A. 1993. The influence of riparian management on the habitat structure and macroinvertebrate communities of upland streams draining plantation forests. The Journal of Applied Ecology, Vol. 30, pp. 13-24. https://doi.org/10.2307/2404266

17. Porvari, P., Verta, M., Munthe, J., Haapanen, M. 2003. Forestry practices increase mercury and methyl mercury output from boreal forest catchments. Environmental Science and Technology, Vol. 37, pp. 2389-2393. 